\title{
REVIEW
}

\section{Natural fiber reinforced polymer composites: history, types, advantages and applications}

\author{
Kamrun N. Keya ${ }^{1} \quad$ Nasrin A. Kona ${ }^{1} \quad$ Farjana A. Koly ${ }^{1} \quad$ Kazi Madina Maraz $^{1}$ \\ Md. Naimul Islam ${ }^{1}$ Ruhul A. Khan ${ }^{1^{*}}$
}

\begin{abstract}
Nowadays, the use of natural fiber reinforced polymer-based composites is gradually increasing day by day for their many advantages for civil engineering construction applications. Due to their many advantages for polymer-based composite materials are widely used in civil construction, automobiles, aerospace, and many others. Natural fibers such as jute, kenaf, pineapple, sugarcane, hemp, oil palm, flax, and leaf, etc. are cheap, environmentally friendly, renewable, completely and partially biodegradable which can be utilized to obtain new high-performance polymer materials. These composites are having satisfactory mechanical properties (i.e. tensile properties, flexural stress-strain behavior, fracture toughness, and fracture strength) which make them more attractive than other composites. Due to easy availability and renewability, natural fibers can be used as an alternative of synthetic fibers as a reinforcing agent. The aim of this paper is to review different natural fibers reinforced based polymer composites with mechanical characterization, applications, also shows the opportunities, challenges and future demand of natural composite material towards civil applications.
\end{abstract}

Keywords: natural fiber, mechanical properties, polymer composites

\section{Introduction}

Composite materials have been using for thousands of years. On that time, they have manufactured bricks using mud which is made based on thousand-year-old technology. The composite term at first used in 1500 B.C. Early Egyptians and Mesopotamian builders and artisans made strong and durable buildings using a mixture of mud and straw. To make ancient composite products e.g. pottery and boats, straw was used to provide reinforcement. After that, on 25 B.C. ten books on Architecture explained the concrete structure and also described various types of lime and mortars. From the ancient period, engineers, builders, artisans, and manufacturers were tried to develop the application of the composites materials in a different field in a more sophisticated way. In 1200 AD, Mongols designed the first composite bows which were made a combination of bamboo, wood, horns, cattle tendons and silk bonded with natural pine resin which was

\footnotetext{
Received: April 21, 2019 Accepted: June 9, 2019 Published: June 11, 2019

* Correspondence to: Ruhul A. Khan, Polymer Composite Laboratory, Institute of Radiation and Polymer Technology, Bangladesh Atomic Energy Commission, Dhaka 1000 Bangladesh; Email: dr.ruhul_khan@yahoo.com

${ }^{1}$ Polymer Composite Laboratory, Institute of Radiation and Polymer Technology, Bangladesh Atomic Energy Commission, Dhaka 1000, Bangladesh

Citation: Keya KN, Kona NA, Koly FA, et al. Natural fiber reinforced polymer composites -history, types, advantages and applications. Mater Eng Res, 2019, 1(2): 69-85.

Copyright: (c) 2019 Ruhul A. Khan, et al. This is an open access article distributed under the terms of the Creative Commons Attribution License, which permits unrestricted use, distribution, and reproduction in any medium, provided the original author and source are credited.
}

most powerful and most accurate weapons until the 14th century. After that, from 1870 to 1890 , the development of the composites material started to change because of the chemical revolution. Using the polymerization technique, new synthetic resins were converted liquid to solid state in a cross-linked molecular structure whereas previously, synthetic resins contained celluloid, melamine, and Bakelite. In the modern era, the development of the composites materials was not started until scientist were focused on the development of plastics. In the early 1900s, plastics materials such as vinyl, polystyrene, phenolic, and polyester were created and reinforced. In 1907, the first plastics Bakelite was made using synthetic components. These new synthetic materials were provided better performance than other composites materials. However, for structural applications, plastic alone could not provide enough strength and rigidity. So, for the improvement of the strength and rigidity of the structure, it's urgent to provide more reinforcement. In 1935, Owens Corning first announced the first glass fiber and introduced the fiber reinforced polymer (FRP) industry. The development of resins was started from the 1930s, as we know it which methods/ techniques still used in the composites industry today. Combination of fiberglass and a plastic polymer produces an amazing robust structure. Unsaturated polyester resins (UPR) were patented in 1936. Other higher performance resin systems were 
started to use from $1938 .^{[1,2]}$

Nowadays, people start to depend on composite materials and they start to utilize composite material in different aspects. Natural fiber composite materials are eco-friendly, lightweight, strong, renewable, cheap, biodegradable and sustainable. Natural fiber has good properties compared to synthetic fiber. ${ }^{[1]}$ Recently, natural fibers used as an alternative reinforcement in polymer composites which has gained attention among many researchers and scientists due to their advantages over conventional synthetic materials. ${ }^{[3]}$ These natural fibers include jute, hemp, sisal, kenaf, coir, banana, bamboo, sugarcane, flax, and many others ${ }^{[4]}$ which provide good mechanical properties compared to man-made fibers and their cost are reasonable, they are recyclable and renewable, reduce energy consumption, less health risk and nonabrasive to the equipment, non-irritation to the skin. ${ }^{[5]}$ It can be used as a reinforced material because of its thermoplastic and thermosetting behavior. Thermosetting resins such as epoxy, unsaturated polyester resin, polyester, polyurethane, and phenolic are commonly used for manufacturing composites material which composite material gives a higher performance in various applications. They provide adequate mechanical properties and their price is reasonable. Because of their good properties such as high strength, low density, and ecological advantages over conventional composites, natural fibers are getting more attention among academician, researchers, and students and also in industry. Due to their non-carcinogenic and bio-degradable, the use of natural composites is increasing day by day. In 2010, U\$2.1 billion natural fiber reinforced polymer composites (NFPC) used in different industry sector around the whole world and after that industry will keep huge interest on the NFPC and after 5 years (20112016), the NFPCs industry is expected to increase the use of natural fiber around 10\%. ${ }^{[2]}$ Natural fiber is very cost effective material that why its use in different sectors such as aerospace, packaging, automobile, building and construction sectors, railway coach interiors and storage device and also is used as a replacement of high-cost glass fiber. ${ }^{[6-8]}$ Though natural fiber has several advantages (i.e. low density, low cost, biodegradability, etc.), it has some disadvantages as well such as high moisture absorption. Therefore, chemical treatments are necessary to control high moisture absorption. After chemical treatment, the mechanical properties of the natural fibers are greatly affected by many factors such as fiber length, fiber aspect ratio, fiber-matrix adhesion, etc. Several research works have been already done using a natural fiber.

Thwe and $\mathrm{Liao}^{[9]}$ studied the mechanical properties of bamboo fiber reinforced based composite, the effect of bamboo fiber content, fiber length, bamboo to glass fiber ratio and shows the mechanical properties of bambooglass fiber reinforced plastics. Jiang et al. ${ }^{[10]}$ discussed the mechanical behavior of poly (3-hydroxybutyrateco-3-Hydroxyvalerate) with bamboo fiber composites. Okubo et al. ${ }^{[11]}$ developed new composite material using bamboo fiber and polypropylene and studied the mechanical behavior of that composites.

Braga R. A, et $a l^{[12]}$ studied the mechanical and thermal properties of polyester hybrid composites (i.e. jute and glass fiber) and compared and analyzed their properties (i.e. flexural, thermal, density and impact properties). He explained in his paper that jute fiber based composites showed a better composition than glass fiber.

A. Balaji et al ${ }^{[13]}$ discussed about the utilization and future of natural fibers and bio-composite material and also discussed their applications which can be used in making industrial products because of its eco-friendly behavior, low cost, easily available behavior. Natural fiber and bio-composites are used to make household furniture, fencing, window, decking, flooring, sports equipment, lightweight automobile components etc.

In this paper, a review of natural fiber and natural fiber based reinforced composite is studied. The paper emphasizes on the type of the natural fiber, their physical and mechanical properties, their application on different aspects, advantages, disadvantages and also address some of the basic issues to solve the limitation of the natural fiber polymer based composites.

\section{Natural fiber}

Natural fibers are simple fibers which are manmade or not synthetic. Natural fiber can be found in plants and animals. ${ }^{[3]}$ The use of natural fiber from both resources is renewable and nonrenewable. There are many types of natural cellulose fiber such as flax, hemp, sisal, banana, kenaf, jute, and oil palm fruit bunch cellulose fiber. Composite materials made from jute fiber gained considerably more attention in the last few decades, so far. The plants, which produce cellulose fibers can be classified into bast fibers (jute, flax, ramie, hemp, and kenaf), seed fibers (cotton, coir, and kapok), leaf fibers (sisal, pineapple, and abaca), grass and reed fibers (rice, corn, and wheat), and core fibers (hemp, kenaf, and jute) as well as all other kinds (wood and roots). ${ }^{[4,5]}$ The plants, which produce cellulose fibers can be classified into bast fibers (jute, flax, ramie, hemp, and kenaf), seed fibers (cotton, coir, and kapok), leaf fibers (sisal, pineapple, and abaca), grass and reed fibers (rice, corn, and wheat), and core fibers (hemp, kenaf, and jute) as well as all other kinds (wood and roots)..$^{[4,7]}$ South East Asia, Indonesia, and 
Malaysia, in particular, being top producers of palm oil, have problems in disposing of the empty fruit bunch cellulose fibers and therefore, it is of interest to convert the waste into useful reinforcement. Advantages of natural fibers as plastic reinforcement are due to its low density, renewability, biodegradability, non-toxicity, good insulation property and machine wear. The low density of natural fibers is very beneficial in the automotive industry. A study has been carried out which, shows that when $30 \%$ of glass fibers is substituted with $65 \%$ of hemp fibers, the net energy saving of 50,000MJ (3 tons of emission) can be achieved. ${ }^{[6]}$

\section{Classification of natural fibers}

Natural fibers are any kind of hair-like raw material which are directly found from vegetable, plant, animal and mineral sources and after that those raw materials are converted into nonwoven fabrics and after that, they can be turned into filaments, thread, or rope and then used as a component of composites materials. They can also be used to make paper. There are thousands of natural fibers available in nature and many researchers are showed their interests on natural fibers, they utilize natural fibers, develop the use of natural fibers and try to improve the properties of composites using natural fibers. ${ }^{[4,7,8]}$ Figure 1 shows the classification of natural fibers. Natural fibers can be found from plant, animal and mineral sources. ${ }^{[14-16]}$ According to their resources, natural fibers can be classified and divided into animal fibers, plant cellulose fibers, and mineral fibers.

(1) Animal Fibers which contains wool, silk, hair/fur, alpaca fiber, avian fiber. It includes sheep's wool, goat hair, like alpaca fiber and mohair from Angora goats, rabbits wool, Siberian weasel, ox hair, hog bristle, camel-hair, horse hair, feathers, and feathers fiber.

(2) Mineral fiber: Mineral fibers are found from nature or sometimes it's required slight modification where it can be categorized as asbestos, ceramic fibers, and Metal fiber. Asbestos is naturally occurring mineral fiber-like serpentine, amphiboles, and anthophyllite; ceramic fibers are glass fibers, aluminum oxide, silicon carbide, and boron carbide; aluminum fibers are one kind of mineral fibers.

(3) Plant fiber: Plant fibers are mainly cellulose fibers. Plant fibers are categorized into primary and secondary depending on their utilization. Primary plants are grown form their fibers while secondary plants are plants extracted from the waste product. This fiber can be further categorized into following:

(a) Seed fiber: Fibers which are collected from the seed and seed case $e . g$. cotton and kapok.

(b) Leaf fiber: These fibers are collected from the

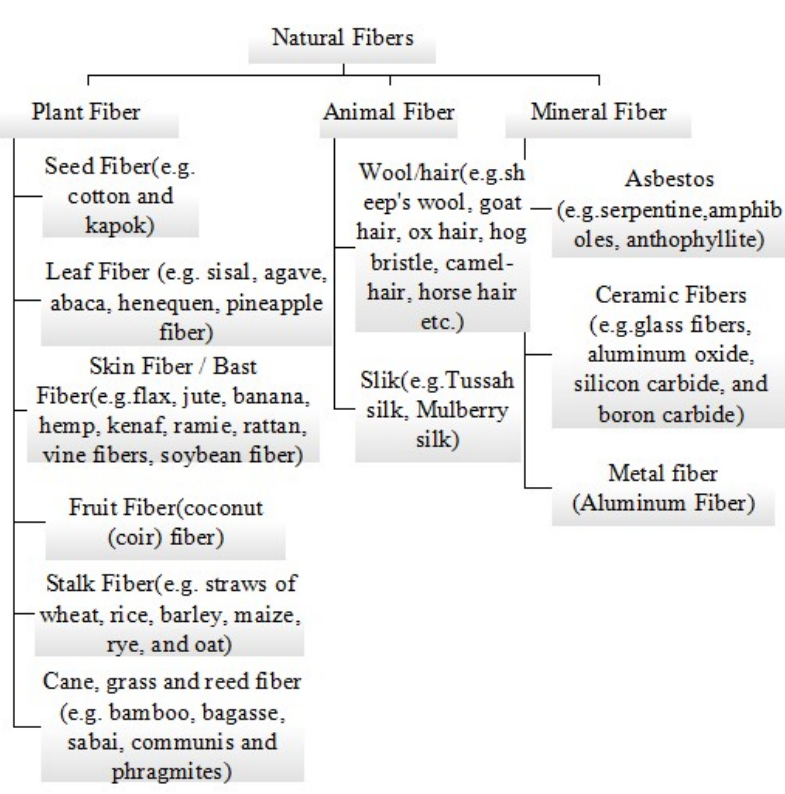

Figure 1. Shows the classification of natural fibers

leaves e.g. sisal, agave, abaca, henequen, pineapple fiber.

(c) Skin fiber or bast fiber: These fibers are collected from the skin or bast surrounding the stem of the plant. Skin or bast fibers have higher tensile strength than other fibers. For that reason, these fibers are used for packaging, fabric, durable yarn, and paper. Such as flax, jute, banana, hemp, kenaf, ramie, rattan, vine fibers, soybean fiber, and banana fibers.

(d) Fruit fiber: These fibers are collected from the fruit of the plant, such as coconut (coir) fiber.

(e) Stalk fiber: Fibers are found from the stalks of the plants such as straws of wheat, rice, barley, maize, rye, and oat.

(f) Cane, grass and reed fiber: Fibers are collected from its original nature source e.g. bamboo, bagasse, sabai, communis, and phragmites.

\section{Different types of natural fibers and their application}

Recently, many researchers are concentrated on natural fiber composites which are intermingled with resins. The natural fiber composites are already used in many engineering applications. The jute, coir, flax, and sisal are discussed below:

\subsection{Jute fiber}

Jute (Corchorus capsularis/ Corchorus olitorius) is bast fibers which is mainly grown for its fiber and it is one of the cheapest natural fibers and also an important fiber after cotton fiber. ${ }^{[17]}$ Corchorus capsularis type of 
jute is found in Indo-Burma including South China, and Corchorus olitorius is found in Africa. The history of jute starts from 206 BC-221 AD; jute paper was found in Dunhuang, Gansu Province, China which was produced jute paper from Western Han Dynasty. ${ }^{[18]}$ Historical documents show that jute fiber was used in India from the 16th century during the era of Mughal Emperor Akbar. The British East India Company exported jute from India. After that, the jute fiber industry grew rapidly around the whole world especially in Dundee, Scotland in 1800. Jute is grown in Bangladesh, India, Myanmar, Nepal, China, Taiwan, Thailand, Vietnam, Cambodia, Brazil, and some other countries. Among them, Bangladesh, India, and China are the best place for the growth of jute. Jute fiber has good insulation properties, high strength to weight ratio, high aspect ratio, good mechanical properties, and good thermal properties. ${ }^{[19]}$ Jute fiber-based composite has been used for making a door, window, furniture, automotive, aircraft, water pipes, false roofing, floor tiles, etc. ${ }^{[20]} \mathrm{T}$. Subash et $a l^{[21]}$ discussed bast fibers reinforced green composites which are used for aircraft indoor structures applications. The natural fibers such as jute, kenaf, bamboo, bagasse, coir, sisal have been provided good materials which are used in the aerospace and automotive industry. Because of its low density and lightweight properties, natural fiber can make sustainable products which can reduce a tremendous amount of energy consumption in the aerospace industry. Jute fiber is used as packaging material (bags), carpet backing, ropes, door, furniture, floor tiles, yarns, and also used for wall decoration. ${ }^{[21]}$ Natural fiber like jute fiber has many advantages such as it has high tensile strength, better water resistance properties, bio-degradable and environmentally friendly.

\subsection{Coir}

Coir fiber comes from the husk of the coconut fiber which has a long life compared to other fibers due to its lignin properties cite22. Coir fiber-reinforced composites can be fabricated with both thermoset and thermoplastic resins. The mechanical properties of the coir composite totally depend on its interfacial adhesion characteristics. $^{[22]}$ Coir fiber reinforced composites manufactured for social, economic and industrial applications such as packaging material, helmets, rope, and finishing nets, brushes, mattresses, automotive interior, paneling and roofing as building materials, postboxes, mirror casing, storage tank, projector cover, voltage stabilizer cover. ${ }^{[23,24]}$ But it has some limitation such as high moisture content which can be treated using chemical treatment. Untreated coir based composite showed less mechanical properties than pretreated coir based com- posite. ${ }^{[28,29]}$ Jute-coir hybrid composites used to make doors and windows beside in the transportation sector, railway coaches for sleeper berth backing, for building interiors. ${ }^{[25]}$

\subsection{Kenaf Fiber}

Kenaf fiber (Hibiscus Cannabinus) is extracted from the bast (outer) and core (inner) fibers of the kenaf plant which shows similar characteristics like jute. Kenaf fiber is found mainly in Africa and Asia. Kenaf plant can grow up to a height of 2.4-6 m within 150 days. ${ }^{[26]}$ The United States commercially use kenaf fiber, they cultivate various types of kenaf which cultivation totally depend on the weather conditions. It has many advantages such as used for fabricating composites, produce twin, rope, sackcloth, ${ }^{[20]}$ paper production, animal foods, manufacture oil, medicine, food additive, ${ }^{[25]}$ and also used for industrial applications, platform for mushroom farming, environmental cleaning, absorbents, automotive industries and textiles, building materials, oil and chemical absorbents. ${ }^{[8,15]}$ Webber III ${ }^{[34]}$ illuminated that kenaf plant possesses many useful component e.g. to stalk, leaves and seeds) and these three component are divided into several usable portions such as fibers and fiber strands, oils, proteins and allelopathic. ${ }^{[28]}$ Kenaf fiber can be affected by many factors such as photosensitivity, plant populations, growing season, planting date, and cultivar and plant maturity. ${ }^{[28]}$ Its fiber properties depend on sources, age and separating technique. ${ }^{[29]} \mathrm{Ke}-$ naf fiber exhibits low density, high mechanical properties and biodegradability.

\subsection{Sisal}

Sisal is produced in East Africa and Brazil which is obtained from the Agave sisalana plant. The plant looks like giant pineapples, during the harvest the leaves are removed from the pulp and plant material and the tough fibers are left behind. Then using hand or machine, soft tissue is worn from the fibers. After that, the fibers are dried and brushed the fibers for removing the remaining dirt from the fiber. Sisal produces strong fiber. It is fully biodegradable, high tenacity, high tensile strength, tough, abrasion resistant material, acid and alkali resistance, corrosion resistance, sea water resistance, ${ }^{[30]}$ green composites. Sisal fiber is too tough for textiles and fabrics and it's not suitable for wall finishing. It is mainly used mats, roofs, carpets, used for cement reinforcement, automobile industry, slippers, clothes, disc buffers. But, the global demand for sisal fiber products is started to decrease since 1998-2000. Sisal fibers are durable, it has a low maintenance cost, recyclable, does not absorb moisture, good sound and impact absorbing properties. ${ }^{[29]}$ 


\subsection{Flax}

Flax is one kind of cellulosic natural fibers and it is bast fiber also. Flax fiber is grown in temperate regions and it's extracted from the skin of the stem of its own plant and then manufactured into linen yarn. It is one of the oldest fibers and now it is mainly used for several composite applications. Flax fiber is flexible, lustrous, it has good abrasion resistance, and it can absorb moisture and dry quickly. Day by day flax fiber reinforce based composites value getting higher in textile markets because flax fiber is two-three times stronger than cotton fiber. There are other advantages of flax fibers as well such as low density, high strength and stiffness, high toughness and biodegradability. ${ }^{[31]}$ Flax fiber is used as a raw material in the paper industry, manufacturing rope and twine, for canvas and webbing equipment and also used as table wear, clothing apparel, sewing thread, surgical thread, decorative fabrics, etc.

\subsection{Hemp}

Hemp is another important member of bast fibers which is naturally environmentally friendly and oldest fiber and it grows in temperate climates. Hemp fibers always provide excellent mechanical strength and youngs modulus. Hemp fiber is used in textile, paper, and rope and oil production industries. It was first used in Asia. Currently, the European Union uses hemp fiber for nonfood agriculture. Hemp fiber is stronger, more absorbent, more resistant, high tensile strength, high luster, and durable than cotton fiber. Hemp fiber is used in rug and carpet manufacturing and also used for ship cordage as it is not rotted by water. Hemp fibers are used for interior design, apparel fabrics, also hemp fiber is used for blocking the sun's harmful ultraviolet rays. A recent report shows that one-third of the total production in China is based on hemp fiber. ${ }^{[32,33]}$ However, the application of hemp fiber is still limited in the textile industry.

\subsection{Bagasse}

Bagasse is the fibrous residue which remains after sugars are extracted from the sugarcane. It is extracted from renewable resources. It is one of the most eco-friendly fibers which is used for a various application such as a biofuel in renewable power generation and also used to manufacture the composites materials. ${ }^{[5,36]}$

\subsection{Pineapple Leaf Fiber (PALF)}

Pineapple is a native tropical plant which was first found on the island of West Indies, South America and Brazil. $^{[34,35]}$ Nowadays, different types of pineapple plants are available which are utilized as a fabric for in- dustrial applications, medicinal, edible, textile materials and in the manufacture of yarns and handicrafts in many countries. PALF is relatively inexpensive, good chemical compositions, higher mechanical strength than jute fiber, high specific strength, rigidity, and flexural and high torsional rigidity. PALF can be used as a raw material in the industries to make the reinforcing composite matrixes. ${ }^{[5,36]}$

\subsection{Bamboo Fiber}

Bamboo fibers are cellulose fiber which is extracted from natural bamboo. A mature bamboo plant grows up to $40 \mathrm{~m}$ and within six to eight months bamboo can reach its mature size. Recently, bamboo fibers are getting more attention on the world market. There are around 1000 species of bamboo recognized worldwide. Bamboo grows very rapidly. Its fiber has many advantages over cotton fiber. Bamboo fiber used as raw material in textiles industries. Its also utilize for making fabric which is known as "Meso". Bamboo fiber is totally environmental friendly fiber which has unique quality antibacterial property, moisture absorption, elasticity, UV resistant. Bamboo fiber has natural antibacterial elements that why it is used building materials. Bamboo fiber is used for manufacturing bathroom products, decorating items, hygiene products, etc. ${ }^{[37,38]}$

\subsection{Abaca}

The abaca collects from the stalk of the plant which is durable and resistant to seawater. Abaca fiber has many advantages such as low density, appropriate stiffness, and mechanical properties and high disposability and renewability, recyclable and biodegradable. It is one of the strongest cellulose fibers which is used for marine applications, resistant to saltwater, commonly used for fishing nets, used for meat casings and also abaca fiber is used in the production of the tea bags; also utilize as a raw material and that raw material is used in the processing of high-quality paper, machinery filters, hospital textiles, electric conductor, etc. ${ }^{[5,36]}$

\section{Composite material}

The composite material is a combination of two or more materials such as reinforcement, fillers, and a binder which are used in a different composition. Composites are hybrid materials made of a polymer resin reinforced by fibers, combining the high mechanical and physical performance of the fibers and the appearance, bonding and physical properties of polymers, the short and discontinuous fiber composites are responsible for the biggest share of successful applications, whether 

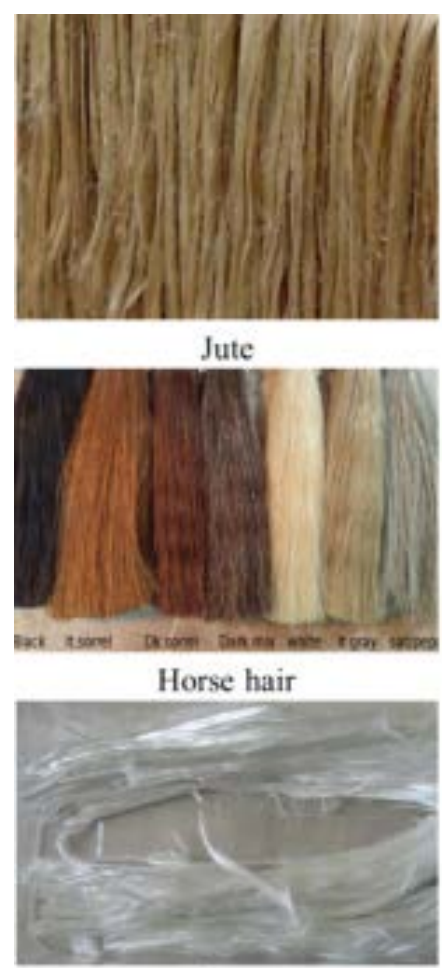

Asbestos
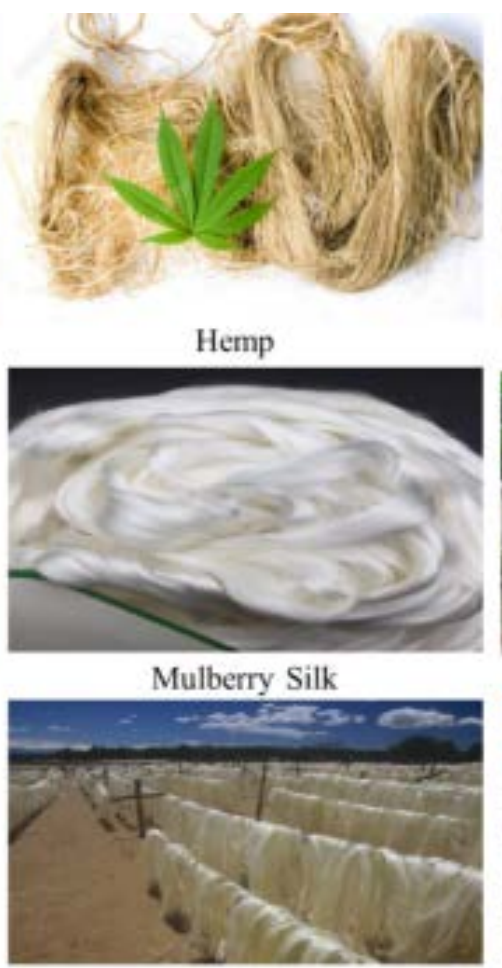

Sisal

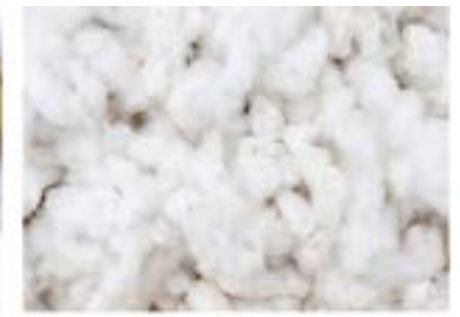

Cotton

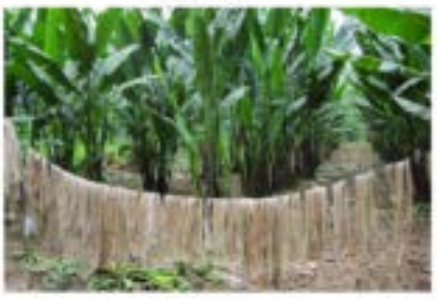

Banana

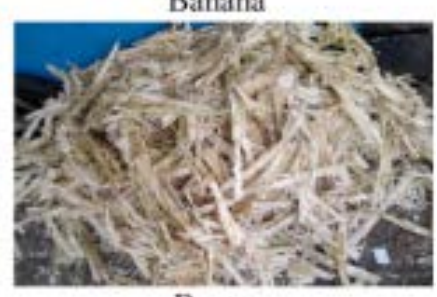

Bagasse

Figure 2. Photographs of sources of some natural fibers

measured by the number of parts or quantity of material used.

\section{Why composites?}

Nowadays, advantages of composite materials over conventional materials increasing for its higher specific strength, higher water absorption quality and inferior fire resistance, stiffness and fatigue characteristics. Over the past few decades, polymer composites materials used as a replacement of conventional materials in various applications. It can meet diverse design requirements and because of its good mechanical and physical properties, composites materials meet the requirements of a particular application. The properties and advantages of the polymer composites are given below: ${ }^{[5,39]}$

(1) Composite materials have good adaptability in a different situation. Because when any fiber (e.g. jute) combined with other materials to serve a specific purpose, it shows better physic-mechanical properties than other materials.

(2) The tensile strength of composites is around four to six times higher than steel or aluminum.

(3) The strength-weight ratio of the composite material is higher than other materials.

(4) The composite material has high stiffness ratio, high mechanical strength than other non-composite materials.

(5) Composite materials are lighter materials than other materials. Its weight is lighter compared to woods and metals. Because of these properties, composite materials are used in automobile and aircraft. Less weight means better fuel efficiency that means it will increase the speed of the aircraft.

(6) Composites have a good resistance quality. Composites can resist damage from the weather. It has good properties where chemicals are stored.

(7) It has high-impact strength, composites have a quality to absorb impacts.

(8) Composite materials are used to eliminate joints and providing simplification and integrating design compared to other conventional materials.

(9) Composites show outstanding corrosion resistance and fire retardancy.

(10) Using composites materials, the designer can able to create almost any complex shape or form and it already meets performance needs and complex design requirements. So, the designer gets more flexibility when they design complex structures.

(11) Composites are works as a good insulator. It shows excellent thermal properties.

(12) Composites materials have a long life which re- 
quires little maintenance. Many composites offer good impact, fatigue, and environmental resistance.

\section{Physical and mechanical properties of nat- ural fiber composites}

The advantage of natural fiber over synthetic fiber is increasing rapidly because of its low cost, less weight, low manufacturing cost, abundance, renewable resources, relatively good physical and mechanical properties such as tensile strength, tensile modulus, bending strength and bio-degradable and environmentally friendly qualities. Natural fibers have been cultivated and used especially in rural developing countries for creating non-structural applications such as bag, broom, fishnet, and filters. Natural fibers also can be used as a roof material and wall insulation. A large variation is found when we compare the properties of natural fiber. ${ }^{[40]} \mathrm{Sev}$ eral factors like the kind of natural fibers, surface chemistry between fiber, type of fibers, moisture content and form of fibers and other composition (e.g. epoxy resin) and the quality of the interface that must be considered to achieve desired mechanical properties of the natural fiber reinforced based composites. The properties of the natural fibers depend on the types of natural fibers, their cultivation, growing period and retting or extracting process, ${ }^{[39-41]}$ isolation and processing method. ${ }^{[40]}$ Many researched have been carried out to find the impact of the fiber types and processing methods on tensile strength, Young's modulus, density, and elongation at break of the natural fiber composites (Mueller and Krobjilowski 2004; Mukhopadhyay and Fangueiro 2009; Bledzki and Jazzkiewiez 2010). Mechanical properties of the natural fibers especially flax, abaca, kenaf, ramie, hemp, jute, sisal, bamboo, and bagasse are very good and strength and modulus are higher than synthetic fiber. ${ }^{[42]}$ Table 1 shows the type and mechanical properties of the common natural fibers. It is shown in the table that flax and kevlar 49 have higher tensile strength than other natural fibers and another things we can observed from the table that natural fibers have low density and reasonable Young's modulus. ${ }^{[7]}$

\section{Application of natural fiber composite ma- terial}

Natural fiber reinforced composites are promising and elegant materials. Because of their durability and integrity, the utilization of natural fiber based composite materials is increasing day by day ${ }^{[58]}$ Nowadays, natural fiber reinforced based composite materials is used almost in every type of advanced engineering structures. Their usage includes various components in aircraft, automobiles, helicopters, spacecraft, boats, ships, offshore platforms and also used in chemical processing equipment, sports goods, and civil infrastructure such as buildings and bridges. ${ }^{[59]}$ Now several industries are encouraged to use natural fibers because those products are more environmentally sound and reduce their dependence on fossil fuels. ${ }^{[61]}$ The worldwide use of natural fiber composites has been grown to market around 11\% from 2014 to 2019 , and its extent $\$ 531.2$ million in 2016 , then market share of the natural fibers are increased around 28\%. ${ }^{[60]}$ Application of the natural fiber composites are given below:

\subsection{In Aerospace applications}

Approximately 50\% components of the airspace are made from natural composites. Wright Brothers' Flyer 1, was the first flight where they used natural fiber composites e.g. wood and fabrics. ${ }^{[62]}$ Currently, natural composites are used to develop the helicopters, military fighter aircraft, small and big civil transport aircraft, cockpit, satellites, launch vehicles and missiles because those natural composite have properties to reduce the weight of the aircrafts. Rudder, spoilers, LG doors, engine cowlings, keel beam, airbrakes, elevators, turbine engine fan blades, propellers, rear bulkhead, wing ribs, main wings, Interior components etc. those all components of the aircrafts are fabricated using natural composites. ${ }^{[63]}$ Figure 3 shows that the Cockpit is also made of composite material. Gururaja $\mathrm{M} \mathrm{N}$ et al. ${ }^{[64]}$ provide a review on current uses and future scope and applications of hybrid composites which are used for manufacturing automotive, aerospace, marine, wind power etc. because of its availability and good mechanical properties.

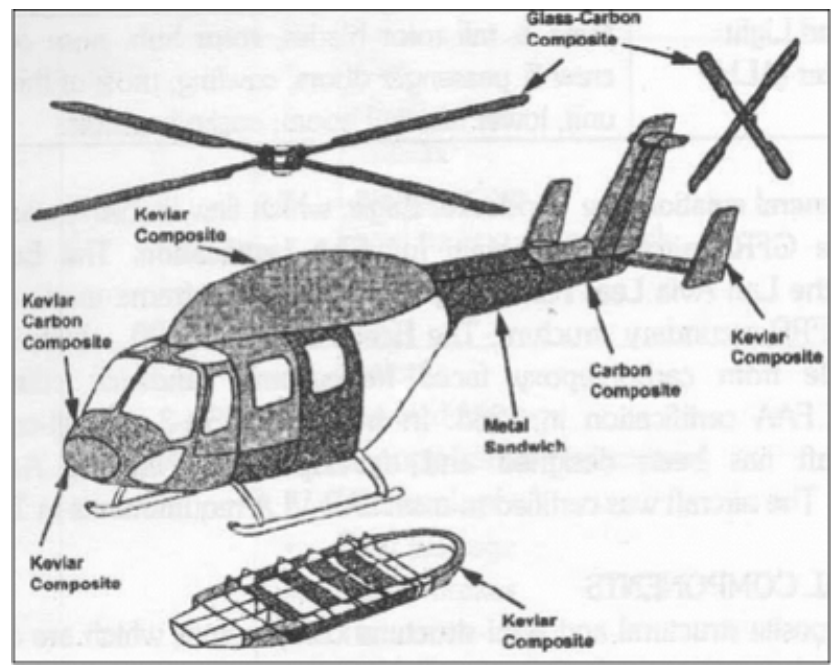

Figure 3. The Cockpit is made of composite material 
Table 1. Shows different kind of natural fiber mechanical properties for composites applications

\begin{tabular}{cccccc}
\hline Fiber & $\begin{array}{c}\text { Tensile Strength } \\
(\mathrm{MPa})\end{array}$ & $\begin{array}{c}\text { Elongation at Break } \\
(\%)\end{array}$ & $\begin{array}{c}\text { Young's modulus } \\
(\mathrm{GPa})\end{array}$ & $\begin{array}{c}\text { Density } \\
\left(\mathrm{g} / \mathrm{cm}^{3}\right)\end{array}$ & Reference \\
\hline Jute & $400-800$ & 1.5 & $10-30$ & 1.46 & {$[43]$} \\
Sisal & $400-700$ & $05-14$ & $09-12$ & 1.45 & {$[44]$} \\
Coir & 175 & 30 & $4-6$ & 1.2 & {$[45]$} \\
Hemp & $550-900$ & 1.6 & 70 & 1.48 & {$[46]$} \\
Cotton & $287-597$ & $2-10$ & $6-10$ & 1.21 & {$[47]$} \\
Pineapple & 413 & 1.6 & 6.21 & 1.526 & {$[48]$} \\
Abaca & 980 & $10-12$ & $9.0-28$ & 1.5 & {$[49]$} \\
Kenaf & 930 & 1.6 & 53 & 1.45 & {$[50]$} \\
Ramie & $511-635$ & $3.6-3.8$ & $9.4-22$ & 1.5 & {$[51]$} \\
Oil palm & 71 & 11 & 1.703 & - & {$[52]$} \\
Flax & $500-1500$ & $2.7-3.2$ & 27.6 & - & {$[53]$} \\
Banana & 10.854 & 6.085 & 1.63 & 1.02 & {$[54]$} \\
Bagasse & 290 & 1.1 & 17 & 1.25 & {$[13]$} \\
Kevlar 49 & 3650 & 2.5 & 124 & 1.44 & {$[55]$} \\
Date palm & $97-196$ & $2-4.50$ & $2.50-5.40$ & $1-1.20$ & {$[56]$} \\
Bamboo & $73-505$ & 4.11 & $10-40$ & 4.3 & {$[57]$} \\
\hline
\end{tabular}

\subsection{In Automotive industry}

From the past few decades, composites are used to make low weight, safer, easy to recycle and more fuelefficient vehicles. ${ }^{[65]}$ The natural fiber composites have been started to use in automotive industries from the 1990s. The main components of the car like interior door panels, roofs, seat backboards, trunks, dashboards, hatch, mats, exterior panels, wheels, etc. are fabricated by natural fibers, Figure $4 .{ }^{[66]}$ The automobile industrys annual demand for natural fiber increasing day by day and in 2005, around 45,000 tons of natural fibers used in the automotive industry. ${ }^{[66]}$ Still, in these sectors, natural fiber composites are most widely applied. German auto companies (BMW, Mercedes, Volkswagen, Audi Group, Ford, Opel, and Daimler Chrysler) use natural fiber to make door panels, headliner panel, boot lining, seat backs, noise insulation panels, molded foot, and well linings for BMW; seat back, side and back door panel, boot lining, hat rack, and spare tire lining are fabricated from natural fiber to make Audi. Door panels, B-pillars, and boot lining are made from natural fiber to create Ford. Internal engine cover, engine insulation, sun visor, interior insulation, bumper, wheel box, and roof cover are fabricated from natural fiber to make MercedesBenz. Other automotive companies like Proton company
(Malaysian national carmaker), and Cambridge industry (an auto industry in the United States) are manufactured different components of the car using natural composites, mainly based on polyester or polypropylene, and fibers like hemp, flax, jute, or sisal. Because of marketing demand rather than technical demands, the global demand for natural fiber reinforced composites in the automotive industry is increasing rapidly. ${ }^{[67]}$

Gururaja $\mathrm{M} \mathrm{N}$ et al. ${ }^{[62]}$ give a review on recent applications and future scope of hybrid composites material and the Author concluded that hybrid composite materials are used in automotive, aerospace, marine, wind power, etc. The hemp fiber has been used for manufacturing lightweight designed seats for the car.
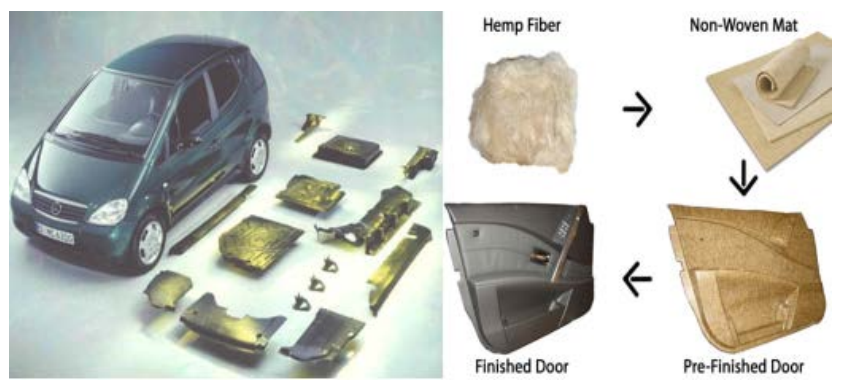

Figure 4. Production of door from hemp fiber 


\subsection{In Chemical Industry}

In the chemical industry, composite materials are used because of their fire resistance properties, lightweight, moldability, and resistance to chemicals properties. Chemical industries are used to make drive shaft, ducts, stacks, fan blades, underground storage tanks, casings, composite vessels columns, reactors, ducting, piping, etc. $^{[62]}$

\subsection{In medical sector}

Nowadays the use of composite materials is increasing rapidly and it is also started to implement in medical applications as well. A composite material is now used as a medical device and those materials are interacted with the biological system to improve its quality. Over the past few decades, the composite material has used in many ways; sometimes it utilizes to improve synthetic materials, to develop surgical technique and sterilization methods. Some composite materials used in different medical applications nowadays. Composite materials have found to use in orthopedic applications, particularly in hip joint replacement, bone fixation plates, bone cement, and bone grafts. Composite materials are also used in clinical practice to restore anterior and posterior teeth. The damaged or missing tooth is replaced using composite materials and its one kind of artificial permanent implant. Currently, in medical sector composite materials used a lot to improve the quality of life of the patient such as vascular grafts, intraocular lenses, pacemakers, biosensors, heart valves, artificial hearts, sometimes use to restore the functions of the body like tissues or organs, etc. ${ }^{[62]}$ Figure 5 shows that composite materials are used to replace worn amalgam.

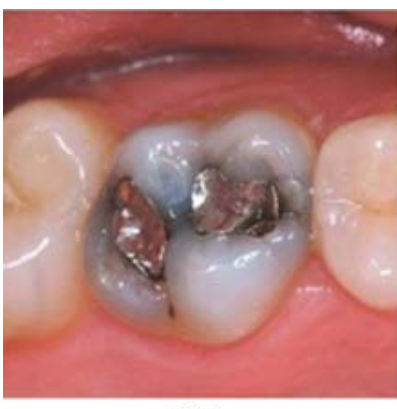

Before

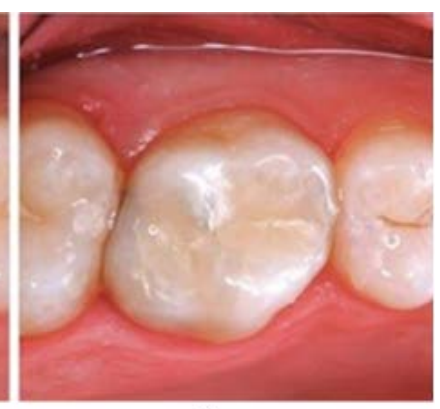

After
Figure 5. Worn Amalgam replaced with composite materials

\subsection{In sports}

Composite materials are used for making sports equipment because of their characteristics like lightweight, low maintenance and durability, superior thermo stabil- ity, friction resistance, abrasion resistance and vibration attenuation, high design freedom, high strength and high design freedom and can be managed and shaped easily, so composite materials now widely used in making sports equipment. Several sports materials are now made using composite materials $e . g$. skis, surfboards, windsurfing, tennis boards, slats, badminton, fishing rods, golf clubs, golf club heads, sword, climbing ropes various lines, etc. are fabricated from natural fiber composites. ${ }^{[68,69]}$ When composite materials are used to make sports equipment, which improved around 30\% 50\% mechanical properties of that equipment. Mechanical performance is good and the weight is lighter than the other sports materials. Because of its excellent mechanical properties like degrees, modulus and elastic modulus, sports equipment are more suitable for use in. ${ }^{[69]}$

\subsection{In electrical field}

Composite materials have high strength, low thermal expansion, high thermal conductivity, low dielectric constant and high/low electrical conductivity which is an important requirement for the electric field. Natural fiberbased composite materials not only use as an insulator but also behave as a conductor which is used in the electric field. The composite materials sometimes utilize as connectors, terminals, household plugs, switches, circuit boards, etc. the electrical applications of natural fiber based composite materials have been determined based on dielectric constant, loss factor and volume resistivity. ${ }^{[70]}$ Electric properties of pineapple reinforced polyethylene composites have been studied by Jayamol et al. ${ }^{[71]}$ The electric properties of sisal fiber reinforced composite showed that the composite has electric anisotropic behavior. Saxena et al. have studied the variation of thermal conductivity and thermal diffusivity of banana fiber reinforced polyester composite and also add glass fiber with banana fiber to improve its thermal conductivity properties and they found that the thermal conductivity of composites increased when they mixed different types of fiber together and made a new composite matrix. ${ }^{[72]}$ They also found that when they increased the percentage of glass fiber thermal conductivity of the composites increased and decreases when they used only pure banana fiber. Electronics composites can be used as an expensive filler, e.g. silver particles, which electronics composites deliver high electrical conductivity. The application of electronics composites in electronics include interconnections, fuel cell devices, electronic packaging, capacitors, thermistors, dielectrics, piezoelectric functions and ferroelectric memories, printed circuit boards, interlayer dielectrics, die to attach, lids, thermal interface materials, electrical contacts, connectors, heat sinks, 
housings, etc. ${ }^{[73,74]}$

\subsection{Boards of musical instruments}

Now, various types of musical instrument components are made from composite materials including saxophone reeds, neck stiffeners, bows, and string instrument top plates. Composite materials are used to make musical instruments and it's replaced the wood. Composite materials made of fibers and resin has the purpose to imitate the wood structure and from 1975 composite materials were used to make guitar and violin top plates. ${ }^{[75]}$ Figure 6 shows musical instruments (i.e. composite guitar and violin top plates) which are made of composite material. There are several reasons to choose composite materials for making musical instruments. Because it has some properties like less material variability, lower production time, better resistance to environmental changes. Natural fibers such as bamboo and wood fibers based composite materials have been used to make in several musical applications. ${ }^{[76]}$ But because of the shortage of wood or bamboo, people are willing to use different kinds of composite materials as well such as bast fiber, flax fiber, etc. Phillips and Lessard ${ }^{[77]}$ studied the application of flax fiber composites in guitar boards and compared them with the properties of Sitka spruce and they found that flax fiber composites can substitute for Sitka spruce. The German company Jakob Winter manufactured violin boards and saxophone cases using hemp or flax fiber and PP matrix and that composition creates a promising market product. Furthermore, the American company Blackbird manufactured guitar ( Figure 6) boards with a composite of linen fiber fabric and bioresins and using the composition of line fiber and bioresins improved the resistance quality and this composite guitar acoustics characteristic is much better than conventional wood boards.

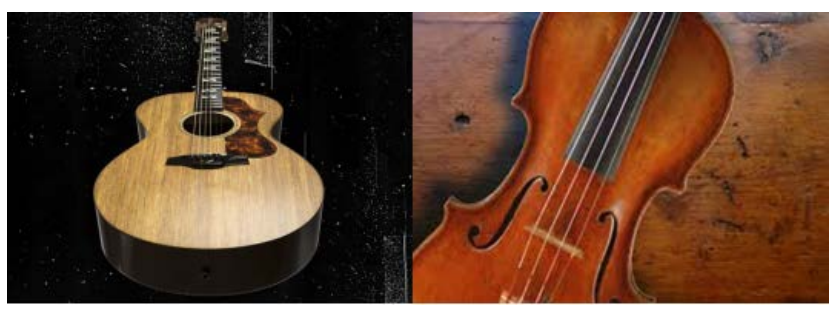

Figure 6. (a) Composite Guitar; (b) Violin top plates made of composites materials

\subsection{Construction materials}

Construction materials is another important application of natural fiber composites. Composite materials play a vital role in the building and construction sector.
Composite materials have been used in several construction sectors such as industrial supports, tanks, long-span roof structures, tanks, high rise building and lightweight doors, window, furniture, lightweight building, bridge components, and complete bridge systems. ${ }^{[78]}$ Day by day in the construction sectors, composite materials play an important role to make sustainable development. The construction sector is now the biggest consumer of raw and natural materials. Because of the increasing number of population, consumer demands to increase rapidly. ${ }^{[?]}$ During the last few decades, researchers are trying to develop new composite materials using different combinations of polymer matrix. After that researchers are started showing interest on the developments of natural fiber composites and their application. Several studies have been already done on natural fiber composites. Researchers are trying to improve the qualities of composites so they may be strong, lightweight, long-lived and inexpensive to produce new composites, so their interest in natural fiber composites increasing gradually. ${ }^{[78]}$ Why researchers show interest to use by-products or wastes of industries or natural fiber reinforced composite because these materials are locally available, renewable, sustainable and able to reduce the environmental related problems and also get more flexible in use and deliver highperformance structures. Now people are paying strong attention in an environment so they try to pay more attention to the development of the recyclable and environmentally sustainable composite materials which can be produced in low cost and which can be prepared from byproducts or wastage. When the use of natural fibers (e.g. as hemp, jute, bagasse, sisal) composites are increasing rapidly in the construction sector, those composites helps in reducing carbon emission which is ecologically and economically beneficial. ${ }^{[5]}$ Now natural fibers have been used for manufacturing several civil engineering construction components such as door, windows, panels, fiber boards, and frames, furniture, and sports goods. ${ }^{[80]}$ In the construction sector wood or timber based composites can be used to manufacture those components. The coir fibers are very strong and when coir fiber with polymers together make a better composite, it can be used for manufacturing of wall panels, false ceiling, partitions, and roofing boards. Wall panels, false ceiling, flooring, roofing, lightweight partition walls, and door windows shutters can be manufactured using rice husk and synthetic resin-based composites. With the help of PVC and jute fiber red mud can be manufactured roofing sheets, panels, etc. which are strong enough to carry the load, cheaper, durable, and efficient and serve as a good construction material. In the construction sector straw and paper also play a vital role, using those materials people 
are already made the false ceiling, light partition walls, wall panels, roofing, and cladding. In China most of the people are relying on natural fiber composites and they are trying to build their building using natural fiber composites like outdoor bed boards, indoor decorative boards, park benches, Bridges components, developed for building beams and columns, ${ }^{[79]}$ fences, and building templates; ${ }^{[80]}$ fittings (towel rails, door and window handles, bathroom accessories), Boards (fascias, door, panels), wall and floor coverings, roof coverings etc. Because of the enormous demand of the natural fiber composites, many non-Chinese construction companies have already started to invest in it and they are willing to use natural fiber composites in several construction sectors. For example, in North America, the Trex, Timber Tech and AERT companies are made decking products using natural fiber composites. Md Iqbal Ahmad et al. ${ }^{[81]}$ analyzed and focused on the earthquake-resistant building constructions. He presented a new framework which is made of composite material and this frame is found most effective in building constructions.

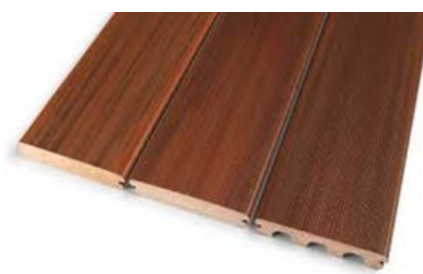

(a)

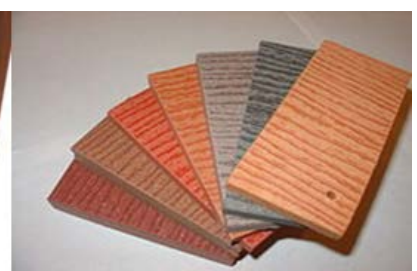

(b)
Figure 7. (a) Composite decking board profiles; (b) WoodPlastics Composite

\subsection{Packaging materials}

Increasing concerns about natural resources and growing global environmental waste problems, people are started to think about using biodegradable packaging materials. The manufacturing company is trying to find another alternative packaging materials, they have started to use natural fiber composites. Most of the resins used in packaging materials are very expensive, degradable resins; but when natural fibers are added with resins it does not only reduce the cost of the materials but also improve the strength, rigidity and thermal deformation of the materials without affecting their degradability. ${ }^{[82]}$ Natural fiber-based packaging materials must be environmental friendly. ${ }^{[83]}$ Nowadays, natural fiber composites are used as packaging material (bags), carpet backing, ropes, yarns, and wall decoration. Earth cycle applied composites prepared of palm fibers and edible resins in fruit trays and flowerpots in nursery gardens. Biosphere Industries used a composite which made from starch and some grass fibers to make tableware and plates, and their composite can be able to degrade within 40days. ${ }^{[62]}$ Natural fiber fabric-biopolymer composites particularly bamboo fiber fabric-PLA composites have been used for packaging materials which are renewable, environmentally friendly materials that can successfully substitute the plastics. Since natural fiber fabric-biopolymer composites have better impact properties, ${ }^{[84]}$ they can be used as a rigid packaging or as protective packaging. FS Korea Company uses wood plastic composites for packaging their products or applications. The products are shown in Figure 8 and Figure 9 which are manufacturing from composite materials. When they utilize sustainable composite packaging, it will automatically improve their products value.
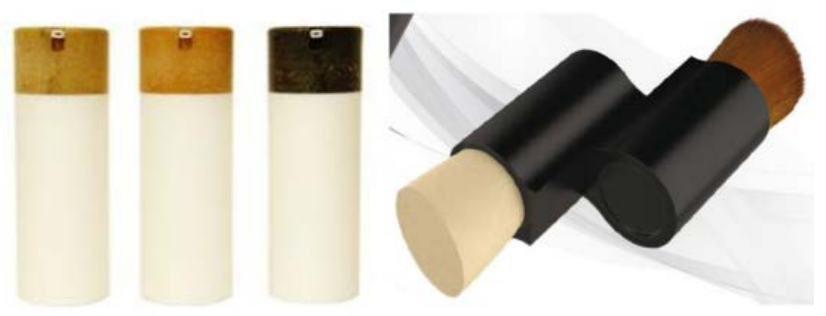

Figure 8. (a) Composite decking board profiles; (b) WoodPlastics Composite

Figure 8 shows an example of perfume containers which is made of wood flour based composites. This product is introduced by the Brazilian branch of Rexam Beauty Packaging which is one of the well-known plastics cosmetic packaging products company. These new products encourage customers to use more biodegradable products. Another example of the packaging materials is laptop casing which is made from hemp/PLA based composites (Figure 9) would be fully recyclable and biodegradable products.

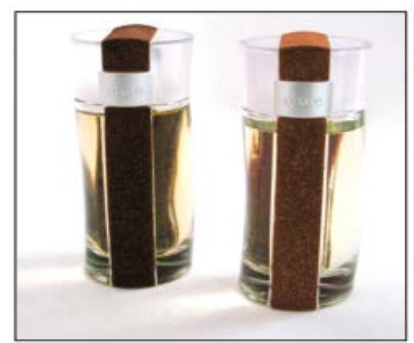

(a)

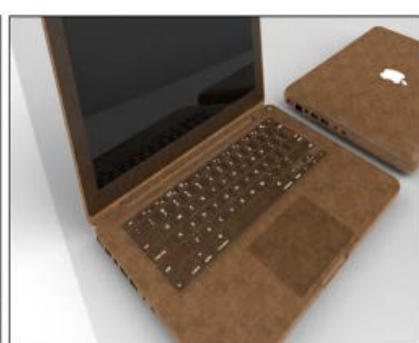

(b)
Figure 9. (a) Containers for perfume molded using wood flour based composites; (b) Laptop casing made from hemp/ PLA based composites

Nowadays, mobile box (Figure 10) is also made of white natural bagasse which improves the eco-friendly 
and biodegradable and also sustainable. And that sustainable packaging structures for mobile are strong enough to protect the mobile. The protective packaging for a lamp bulb is made of recycling paper pulp which is totally biodegradable (Figure 10) and during handling and transportation, this can protect the lamp bulb from the unwanted damage.
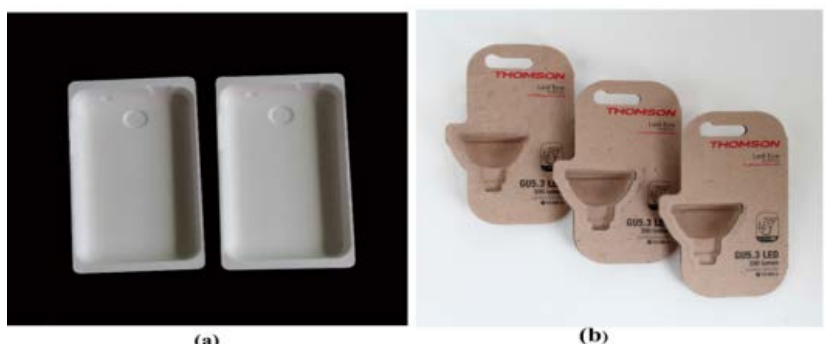

Figure 10. (a) Mobile box made of composite material; (b) Electronic packaging for lamp bulb is made of recycle paper pulp

\section{Advantages of natural fiber composites}

\subsection{High strength}

Metals such as steel or aluminum are used in construction sectors which are provided high strength in all directions. Composite materials can be designed to be stronger than other materials and must be designed in a specific direction.

\subsection{Durable}

When composites are used to build a structure, they have a long life and need little maintenance. Many composites can serve around half a century. But we do not know how long composite structure can be shown its durability and we do not know when original composites have come to the end.

\subsection{Low thermal conductivity}

Natural fiber composites are used as a good insulator. They are used in buildings for doors, windows, and panels to protect the buildings from the weather. Because natural fiber based composites do not easily conduct cold or heat.

\subsection{Strength related to weight}

Strength-to-weight ratio is a material property of the composite material which helps us information about the material and also give us idea how much that material strong, heavy or light. Composite materials are not only strong material but also light material. That's why com- posite materials can be used in aerospace design and automotive industries as well.

\subsection{Light weight}

Composites are lightweight materials that's why it is used in aerospace and automotive applications. Composite materials weight is lighter than any other materials such as woods and metals. Nowadays, composite materials are used in building modern airplanes (i.e. Boeing 787 Dreamliner, Cockpit) because they are now more concern about fuel efficiency which is only possible if we use lightweight composite material.

\subsection{Corrosion resistance and high-impact strength}

Composites have good corrosion resistant and high impact strength properties. It can absorb any things and also it can resist damage from the weather. Composite has good chemical resistance properties. It has an ability to severe in any temperature or weather. Composite materials can be able to absorb any sudden force because of this property, composites are used to make bulletproof vests and panels, and to shield airplanes, buildings, and military vehicles from explosions.

\subsection{Dimensional stability}

Composites are always stay in stable conditions. Their shape, size does not change with weather or temperature. On the other hand, wood shrinks and swells when temperature has changed. Therefore, composites has excellent properties to fit in any situation thats why it is used to build aircraft wings so that wings shape and size do not change in any weather or hot or cool.

\subsection{Nonconductive}

Composites has nonconductive property. That's mean composites are unable to conduct with electricity. Because of this property composite materials are used to make electrical utility poles and the circuit boards. Sometimes electrical conductivity is needed in the composite materials, then it is so easy to convert their properties as a conductive materials.

\subsection{Nonmagnetic}

Composites has nonmagnetic properties and that the only reason composite materials can be used in making housing and table, used around the electronic equipment and also used as a reinforced material which is used to build concrete walls and floors in the hospital. 


\subsection{Radar transparent}

Composites are used to make radar equipment whereas composites material is used in radar for passing signals on the ground or in the air. Composites play an important role to make aircraft such as the U.S. Air Force's B-2 stealth bomber and this stealth bomber is used for transferring signals.

\section{Limitations of natural fibers and solutions}

Among so many advantages, natural fibers possess some disadvantages as well when they are used to produce composite materials. Natural fibers have some drawbacks regarding their performance, the behavior is changed when the polymer is added for manufacturing and processing new composite. The physical properties of the natural fiber are not consistent, their physical properties vary with harvesting season, harvesting reign. Natural fibers properties variation are dependent on the harvesting process, locality, and maturity of the plant and manufacturing process of the fibers, woven or unwoven. All these factors affect the properties of the natural fiber composites. ${ }^{[85]}$ The manufacturing cost of the materials produced by natural fibers is generally expensive. When natural fiber composites used as building materials, it also shows some defects such as less durability due to high moisture, chemical absorption, concrete cracks due to swelling and volume changes, and poor compatibility with polymeric or cementitious matrices. Their poor compatibility with several polymeric matrices shows non-uniform results. To overcome this drawbacks some modification of the natural fibers are needed such as treatment with alkali, saline, water repelling agents, to improve adhesion between matrix chemical coupling or compatibilising ${ }^{[86]}$ methods also used and many researchers have been already used plasma modification of natural fibers and these methods helps to reduce the water absorption of the natural fiber by removing hemicellulose and lignin or by imparting hydrophobicity and also help to improve the interface between natural fiber and polymeric matrix. Chemical coupling agents are used to treating the surface of the matrix. Another drawback is the less stiffness of the composite materials. In the construction sectors, the stiffness of the materials or composites is an important factor to build any civil engineering structure. Though natural fiber composites have high strength, its stiffness is lower than another composite. Overdesigned for the structures are required to solve the problem. ${ }^{[87,88]}$

Another primary drawback of the use of fibers is limited thermal stability. Natural fibers can tolerate temperature is up to $2000 \mathrm{C}$, above this temperature natu- ral fibers are started to degrade and shrink and because of low thermal stability natural fiber composites shows lower performance than other materials. In order to avoid this problem, the range of processing time and the range of temperature has to be limited. ${ }^{[25,26]}$

\section{Conclusion and future demand of the nat- ural fiber}

Natural fiber is biodegradable, eco-friendly and renewable raw material. Natural fiber has good thermal insulation properties and good mechanical properties. But the strength of the natural fiber depends on the loading imposed on the fiber and young modulus of the fiber. It also depends on the fiber weight ratio, cultivation process, fiber extracting process from the plant, harvesting time, manufacturing process and also depend on the fabrication methods of the natural fiber with polymeric matrices. Natural fiber composites are the combination of two different types of materials which create a new versatile material in the field of industrial, engineering and technology.

This paper gives a summary about the natural fibers, types of natural fiber, physical and mechanical properties, advantages of the natural fiber and also discuss the drawbacks of the natural fibers over other materials. In a nutshell, the use of natural fiber is increasing hurriedly in industrial application. Already many research work is done but still, further research and investigation are required to overcome the limitations of the natural fiber such as stiffness of composites, moisture effect, an alkaline solution, fatigue, creep and physical degradation, moisture absorption toughness and reduced long term stability for outdoor application. Even now, many researchers are highly interested in doing their research work on natural fiber and natural fiber based composites. Therefore, the research work on the natural fiber-based composite materials has grown by leaps and bounds over the past few years, because of its durability, renewable, completely or partially recyclable properties.

Despite all of these abovementioned issues, there are several industries are used natural fibers to manufacture new products. The automotive industry and aerospace industry are the most active user of the natural fiber based composites which manufactures non-structural and semi-structural parts; other industries gradually paying more attention to make products using natural fiber composites as well such as sports, medical, furniture, packaging materials, among others. 


\section{References}

[1] May-Pat A, Valadez-González A and Herrera-Franco P J. Effect of fiber surface treatments on the essential work of fracture of HDPE-continuous henequen fiber-reinforced composites. Polymer Testing, 2013, 32(6): 1114-1122. https://doi.org/10.1016/j.polymertesting.2013.06.006

[2] Uddin N, Ed. Developments in Fiber-Reinforced Polymer (FRP) Composites for Civil Engineering. Elsevier, 2013. https://doi.org/10.1533/9780857098955

[3] Saira T, Munawar MA and Khan S. Natural FiberReinforced Polymer Composites. Proceedings of the Pakistan Academy of Sciences, 2007, 44(2): 129-144.

[4] Faruk O, Bledzki AK, Fink HP, et al. Biocomposites Reinforced with Natural Fibers: 2000-2010. Progress in Polymer Science, 2012, 37(11): 1552-1596. https://doi.org/10.1016/j.progpolymsci.2012.04.003

[5] Nguong CW, Lee SNB and Sujan D. A Review on Natural Fibre Reinforced Polymer Composites. International Journal of Materials and Metallurgical Engineering, 2013, 7(1): 52-59.

[6] Zini E and Scandola M. Green Composites: An Overview. Polymer Composites. 2011, 32(12): 1905-1915. https://doi.org/10.1002/pc.21224

[7] Ticoalu A, Aravinthan T and Cardona T. A review of current development in natural fiber composites for structural and infrastructure applications. Southern Region Engineering Conference (SREC'10), Toowoomba, Australia, 2010, 113-117.

[8] Akil HM, Omar MF, Mazuki AAM, et al. Kenaf fiber reinforced composites: A review. Material and Design, 2011, 32(8-9):4107-4121. https://doi.org/10.1016/j.matdes.2011.04.008

[9] Thwe MM and Liao K. Characterization Of Bamboo-Glass Fiber Reinforced Polymer Matrix Hybrid Composite. Journal Of Materials Science Letters, 2000, 19: 1873 - 1876. https://doi.org/10.1023/A:1006731531661

[10] Jiang L, Huang J, Qian J, et al. Study of Poly(3hydroxybutyrate-co-3-hydroxyvalerate) (PHBV)/Bamboo Pulp Fiber Composites: Effects of Nucleation Agent and Compatibilizer. Journal of Polymers and the Environment, 2008, 16(2): 83-93. https://doi.org/10.1007/s10924-008-0086-7

[11] Okubo K, Fujii T and Yamamoto Y. Development of bamboo-based polymer composites and their mechanical properties. Composites Part A: Applied Science and Manufacturing, 2004, 35(3): 377-383. https://doi.org/10.1016/j.compositesa.2003.09.017

[12] Affan Usmani M and Anas M. Study of Natural Fibre Reinforced Composites. IOP Conference Series: Materials Science and Engineering, 2018, 404: 012-048. https://doi.org/10.1088/1757-899X/404/1/012048

[13] Balaji A, Karthikeyan B and Sundar Raj C. Bagasse Fiber The Future Biocomposite Material: A Review. International Journal of Chem Tech Research, 2014-2015, 7(1): 223-233.

[14] Gunti R and Atluri RP. Study on effect of chemical treatments and concentration of jute on tensile properties of long and continuous twisted jute/polypropylene composite. Advanced materials manufacturing and characterization, 2013, 3(1): 395-398. https://doi.org/10.11127/ijammc.2013.02.073
[15] Bongarde US and Shinde VD. Review on natural fiber reinforcement polymer composites, International Journal of Engineering Science and Innovative Technology (IJESIT). 2014, 3(2): 431-436.

[16] Vijay KT, Manju KT and Raju KG. Review: Raw Natural Fiber-Based Polymer Composites. International Journal of Polymer Analysis and Characterization, 2014, 19(3): 256271. https://doi.org/10.1080/1023666X.2014.880016

[17] Ali M. Natural fibres as construction materials. Journal of Civil Engineering and Construction Technology, 2012, 3(3): 80-89. https://doi.org/10.5897/JCECT11.100

[18] Tsien TH. Raw materials for old papermaking in China. Journal of the American Oriental Society, 1973, 93(4): 510519. https://doi.org/10.2307/600169

[19] Staiger MP and Tucker N. Natural-fibre composites in structural applications, Properties and performance of naturalfibre composites, K. L. Pickering, Ed., ed Cambridge: Woodhead Publishing Limited and CRC Press LLC, 2008, 269-300. https://doi.org/10.1533/9781845694593.2.269

[20] Abilash N and Sivapragash M. Environmental benefits of eco-friendly natural fiber reinforced polymeric composite materials. International Journal of application or innovation in Engineering and management (IJAIEM), 2013, 2(1): 53 59.

[21] Athijayamani A, Thiruchitrambalam M, Natarajan U, et al. Effect of Moisture Absorption on the Mechanical Properties of Randomly Oriented Natural Fibers/Polyester Hybrid Composite. Materials Science and Engineering: A, 2009, 517(1): 344-353. https://doi.org/10.1016/j.msea.2009.04.027

[22] Yousif $\mathrm{BF}$ and $\mathrm{Ku} \mathrm{H}$. Suitability of using coir fiber/polymeric composite for the design of liquid storage tanks. Material \& design, 2012, 36: 847-853. https://doi.org/10.1016/j.matdes.2011.01.063

[23] Nadir A, Songklod J, Vallayuth F, et al. Coir Fiber Reinforced Polypropylene Composite Panel for Automotive Interior Applications. Fibers and polymer, 2011, 12(7), 919 926. https://doi.org/10.1007/s12221-011-0919-1

[24] Verma D, Gope PC, Shandilya A, et al. Coir Fiber Reinforcement and Application in Polymer Composites: A Review. Journal of Material Environment science, 2013, 4(2): 263-276.

[25] Charoenvaisarocha AC, Jongjit H and Joseph K. Materials and mechanical properties of pretreated coir-based green composites. Composites: part B, 2009, 40: 633-637. https://doi.org/10.1016/j.compositesb.2009.04.009

[26] Chadramohan D and Marimuthu k. Tensile and Hardness Tests on Natural Fiber Reinforced Polymer Composite Material. International Journal of advanced engineering science and technologies, 2011, 6(1): 97-104.

[27] Babatunde OE, Yatim JM,Ishak MY, et al. Potentials of kenaf fibre in bio-composite production: A review. Jurnal Teknologi (Sciences \& Engineering), 2015, 77(12): 23-30. https://doi.org/10.11113/jt.v77.6304 
[28] Webber CL and Bledsoe VK. Kenaf Yield Components and Plant Composition. Trends in New Crops and New Uses, 2002, 348-357.

[29] Dash D, Samanta S, Gautum SS, et al. Mechanical characterization of natural fiber reinforced composite material. Advanced material manufacturing and characterization, 2013, 3(1): 275-280. https://doi.org/10.11127/ijammc.2013.02.050

[30] Tajuddin $\mathrm{M}$, Ahmad $\mathrm{Z}$ and Ismail $\mathrm{H}$. A review of natural fibers and processing operations for the production of binderless boards. BioResources, 2016, 11(2): 5600-5617.

[31] Zhu JC, Zhu HJ, Njuguna J, et al. Recent Development of Flax Fibres and Their Reinforced Composites Based on Different Polymeric Matrices. Materials (Basel), 2013, 6(11): 5171-5198. https://doi.org/10.3390/ma6115171

[32] Lu N, Swan Jr RH and Ferguson I. Composition, structure, and mechanical properties of hemp fiber reinforced composite with recycled high-density polyethylene matrix. Journal of Composite Materials, 2011, 0(0): 1-11.

[33] Shahzad A. A Study in Physical and Mechanical Properties of Hemp Fibres. Advances in Materials Science and Engineering, 2013, 8: 1-9. https://doi.org/10.1155/2013/325085

[34] Lopattananon N, Panawarangkul K, Sahakaro K, et al. Performance of pineapple leaf fiber-natural rubber composites: the effect of fiber surface treatments. Journal of Applied Polymer Science, 2006, 102(2): 1974-1984. https://doi.org/10.1002/app.24584

[35] Cherian M, Narine S, Souza S F, Sain M, et al. 7 - The use of pineapple leaf fibers (PALFs) as reinforcements in composites. Biofiber Reinforcements in Composite Materials, 2015, 211-235. https://doi.org/10.1533/9781782421276.2.211

[36] Rohit K and Dixit S. A Review - Future Aspect of Natural Fiber Reinforced Composite. Polymers from Renewable Resources, 2016, 7(2): 43-59. https://doi.org/10.1177/204124791600700202

[37] Md Shah A U, Sultan M T H, Jawaid M, et al. A review on the tensile properties of bamboo fiber reinforced polymer composites. BioResource, 2016, 11(4): 10654-10676. https://doi.org/10.15376/biores.11.4.Shah

[38] Lipp-Symonowicz B, Sztajnowski S and Wojciechowska D. New Commercial Fibres Called 'Bamboo Fibres' - Their Structure and Properties. Fibres and Textiles in Eastern Europe, 2011, 19(1): 18-23.

[39] O'Donnell A, Dweib A and Wool R. Natural fiber composites with plant oil-based resin. Composites Science and Technology, 2004, 64(9): 1135-1145. https://doi.org/10.1016/j.compscitech.2003.09.024

[40] Namvar F, Jawaid M, Tahir PM, et al. Potential Use of Plant Fibers and their Composites for biomedical Applications. Cellulosics for Biomed uses, BioResources, 2014, 9(3): 5688-5706. https://doi.org/10.15376/biores.9.3.

[41] Ochi S. Mechanical properties of kenaf fibers and kenaf/PLA composites. Mechanics of Materials, 2008, 40(45): 446-452.

https://doi.org/10.1016/j.mechmat.2007.10.006
[42] Karina M, Onggo H and Syampurwadi A. Physical and Mechanical Properties of Natural Fibers Filled Polypropylene Composites and Its Recycle. Journal of Biological Sciences, 2007, 7: 393-396. https://doi.org/10.3923/jbs.2007.393.396

[43] Eichhorn S and J Mater Sci. Review: Current international research into cellulosic fibres and composites. Journal of Materials Science, 2011, 36(9): 2107-2131.

[44] Maya M G, Soney C George1, Thomasukutty J, et al. Mechanical Properties of Short Sisal Fibre Reinforced Phenol Formaldehyde Eco-Friendly Composites. Polymers from Renewable Resources, 2017, 8(1): 27-42 https://doi.org/10.1177/204124791700800103

[45] Prakash R B, Satish S and Thomas Renald C J. Investigation on Tensile and Flexural Properties of Coir Fiber Reinforced Isophthalic Polyester Composites. International Journal of Current Engineering and Technology, 2014 2: 2347-5161.

[46] Lu N, Swan R H and Ferguson I. Composition, structure, and mechanical properties of hemp fiber reinforced composite with recycled high-density polyethylene matrix. Journal of Composite Materials, 2011, 46(16): 1915-1924. https://doi.org/10.1177/0021998311427778

[47] Gurunathan T, Mohanty S and Nayak S K. A review of the recent developments in biocomposites based on natural fibres and their application perspectives. Compos. Part A. Applied Science and Manufacturing, 2015, 77: 1-25. https://doi.org/10.1016/j.compositesa.2015.06.007

[48] Uma Devi L, Bhagawan S S and Thomas S. Dynamic mechanical properties of pineapple leaf fiber polyester composites. Polymer Composites, 2011, 32(11): 1741-1750. https://doi.org/10.1002/pc.21197

[49] Jawaid M and Abdul Khalil H P S. Cellulosic/synthetic fibre reinforced polymer hybrid composites: a review. Carbohydrate Polymers, 2011, 86(1): 1-18. https://doi.org/10.1016/j.carbpol.2011.04.043

[50] D Nabi Saheb J P Jog. Natural fiber polymer composites: a review. Advances in Polymer Technology, 1999, 18(4):35163.

https://doi.org/10.1002/(SICI)1098-2329(199924)18: 4〈351::AID-ADV6 $\rangle$ 3.3.CO;2-O

[51] M P S T A I G E R, University of Canterbury, New Zealand and N T U C K E R, The New Zealand Institute of Crop and Food Research, New Zealand, Natural-fibre composites in structural applications.

[52] Yusoff MZM, Salit MS and Ismail N. Tensile Properties of Single Oil Palm Empty Fruit Bunch (OPEFB) Fibre (Ciri Ketegangan Gentian Tandan Buah Kosong Kelapa Sawit Tunggal). Sains Malaysiana, 2009, 38(4): 525-529.

[53] Mohanty A K, M Misra L T Drzal. Natural Fibers, Biopolymers and Biocomposites, Boca Raton, FL : Taylor \& Francis. 2015.

[54] Das H, Saikia P and Kalita D. Physico-Mechanical Properties of Banana Fiber Reinforced Polymer Composite as an Alternative Building Material. Key Engineering Materials, Trans Tech Publications, Switzerland, 2015, 650: 131-138. https://doi.org/10.4028/www.scientific.net/KEM.650.131

[55] Engineering ToolBox. Fibre-reinforced Polymer Composites. 2008.[online] Available at: https://www. engineeringtoolbox.com/polymer-composite-fibers- $\mathrm{d}_{-}$ 1226.html. 
[56] Deshmukh T, Patil S, Deshmukh V, et al. Natural Fiber Reinforced Polymer Composite Material-A Review. IOSR Journal of Mechanical and Civil Engineering (IOSRJMCE), 2015: 142-147.

[57] Sen T, Reddy HNJ. Application of Sisal, Bamboo, Coir and Jute Natural Composites in Structural Upgradation, International Journal of Innovation. Management and Technology, 2011, 2(3): 186-191.

[58] May-Pat A, Valadez-Gonzlez A and P J Herrera-Franco. Effect of fiber surface treatments on the essential work of fracture of HDPE-continuous henequen fiber-reinforced composites. Polymer Testing, 2013, 32(6): 1114-1122. https://doi.org/10.1016/j.polymertesting.2013.06.006

[59] Peças P, Carvalho H, Salman H, et al. Review Natural Fibre Composites and Their Applications: A Review. Journal of Composites Science, 2018, 2(66): 1-20. https://doi.org/10.3390/jcs2040066

[60] Rwawiire S, Tomkova B, Militky J, et al. Development of a biocomposite based on green epoxy polymer and natural cellulose fabric (bark cloth) for automotive instrument panel applications. Compos Part B Eng, 2015, 81: 149-57. https://doi.org/10.1016/j.compositesb.2015.06.021

[61] Sun Z. Progress in the research and applications of natural fiber-reinforced polymer matrix composites. Science and Engineering of Composite Materials, 2017, 25(5): 1-12. https://doi.org/10.1515/secm-2016-0072

[62] Gupta G, Kumar A, Tyagi R, et al. Application and Future of Composite Materials: A Review. International Journal of Innovative Research in Science, Engineering and Technology, 2016, 5(5): 6907-6911.

[63] Hinrichsen J. The Material Down-selection Process for A3XX, CAES, 19th European Conference on Materials for Aerospace Applications. Munich, 2000, 6-8.

[64] Gururaja MN, Hari Rao AN. A review on recent applications and future prospectus of hybrid composites. International Journal of Soft Computing and Engineering, 2012, 1(6): $352-355$

[65] Koronis G, Silva A and Fontul M. Green Composite: A review of adequate materials for automotive application. Composites: Part B, 2013, 44: 120-127. https://doi.org/10.1016/j.compositesb.2012.07.004

[66] Pickering KL, Efendy MGA and Le TM. A review of recent developments in natural fibre composites and their mechanical performance. Composites Part A: Applied Science and Manufacturing, 2006, 83: 98-112. https://doi.org/10.1016/j.compositesa.2015.08.038

[67] William-parker. 2018-2023 Natural Fiber Reinforced Composites Market Financial Analysis - Market Current Insights. Growth \& Opportunities, 2019.

[68] Wang JL. Application of Composite Materials on Sports Equipments. Applied Mechanics and Materials, 2002, 155-156: 903-906. https://doi.org/10.4028/www.scientific.net/AMM.155-156. 903

[69] Froes FH. Is the Use of Advanced Materials in Sports Equipment Unethical? JOM, 1997, 15-19. https://doi.org/10.1007/BF02915473

[70] Kumar S, Sangwan P, Dhankhar R, Mor V, et al. Utilization of Rice Husk and Their Ash: A Review. Research Journal of Chemical and Environmental Sciences, 2013, 1(5): 126129.
[71] Jayamol G, Bhagawan SS and Thomas S. Electrical Properties of Pineapple Fibre Reinforced Polyethylene Composites. Journal of Polymer Engineering, 1997, 17(5): 383-404. https://doi.org/10.1515/POLYENG.1997.17.5.383

[72] Saxena NS, Agarwal R, Sharma KB, et al. Thermal Conduction and Diffusion Through Glass Banana Fibre Polyester Composites. Indian Journal of Pure and Applied Physics, 2013, 41(6): 448-452.

[73] Yang X, Zhao X and Hu J. Grading electric field in high voltage insulation using composite materials. IEEE Electrical Insulation Magazine, 2018, 34(1): 15-25. https://doi.org/10.1109/MEI.2018.8246118

[74] Yakovenko O, Matzui L, Danylova G, et al. Electrical Properties of Composite Materials with Electric Field-Assisted Alignment of Nanocarbon Fillers. Nanoscale Research Letters, 2017, 12(1): 471. https://doi.org/10.1186/s11671-017-2244-0

[75] Yakovenko O, Matzui L, Danylova G, et al. Composite materials for musical instruments: The maturity. The Journal of the Acoustical Society of America, 1998, 103(5): 11051106.

[76] Phillips S and Lessard L. Application of natural fiber composites to musical instrument top plates. Journal of Composite Materials, 2011, 46(2): 145-154. https://doi.org/10.1177/0021998311410497

[77] Phillips S and Lessard L. Application of natural fiber composites to musical instrument top. plates. Journal of Composite Materials, 2012, 46: 145-154. https://doi.org/10.1177/0021998311410497

[78] Lila MK, Kumar F and Sharma S. Composites from Waste for Civil Engineering Applications. i-manager's Journal on Material Science, 2013, 1(3): 1-11. https://doi.org/10.26634/jms.1.3.2558

[79] Sanal I and Verma D. Construction Materials Reinforced with Natural Products, Springer International Publishing. Handbook of Ecomaterials, 2017, 1-24. https://doi.org/10.1007/978-3-319-48281-1_75-1

[80] Bakis CE, Bank LC, Brown VL, et al. Fiber-Reinforced Polymer Composites for Construction-State-of-the-Art Review. Journal of Composites for Construction, 2012, 6(2): 73-87. https://doi.org/10.1061/(ASCE)1090-0268(2002)6:2(73)

[81] Ahmad MI, Mallick R, Chakraborty S, et al. Composite Materials: the present scenario, future trends \& its applications focusing on earthquake resistant building constructions. Journal of Civil Engineering and Environmental Technology, 2(12):65-69.

[82] Nurul Fazita MR, Jayaraman K, Bhattacharyya D, et al. Green Composites Made of Bamboo Fabric and Poly (Lactic) Acid for Packaging Applications-A Review. Materials, 2016, 9(6): 435. https://doi.org/10.3390/ma9060435

[83] Lin MC, Lin JH, Lin JY, et al. Plastic packaging materials of laminated composites made of polymer cover sheets and a nonwoven interlayer. Journal of Sandwich Structures \& Materials, 2018, 0(0): 1-15. https://doi.org/10.1177/1099636218795379 
[84] Nurul Fazita MR, Jayaraman K and Bhattacharyya DA. Performance study on composites made from bamboo fabric and poly (lactic acid). The International Journal of Advanced Manufacturing Technology, 2013, 32: 1513-1525. https://doi.org/10.1177/0731684413498296

[85] O'Donnell A, Dweib MA and Wool RP. Natural fiber composites with plant oilbased resin. Composites Science and Technology, 2004, 64: 1135-1145.

https://doi.org/10.1016/j.compscitech.2003.09.024

[86] Bismarck A, Mishra S and Lampke T. Plant fibers as reinforcement for green composites, In: Mohanty AK, Misra M, Drzal TL, editors. Natural fibers, biopolymers, and biocomposites, Boca Raton: Crc Press-Taylor \& Francis Group.
2005.

https://doi.org/10.1201/9780203508206.ch2

[87] Fan M. Future scope and intelligence of natural fibre based construction composites. Advanced High Strength Natural Fibre Composites in Construction, 2017, 545-556. https://doi.org/10.1016/B978-0-08-100411-1.00022-4

[88] Nagavally RR. Composite Materials - History, Types, Fabrication Techniques, Advantages, and Applications. International Journal of Mechanical And Production Engineering, 2017, 5(9): 2320-2092. 